\title{
Assessment of genetic diversity of Turkish and Algerian native sheep breeds
}

\author{
Abdelkader AMEUR AMEUR ${ }^{1,2}$, Onur YILMAZ ${ }^{3}$, Nezih ATA ${ }^{3}$, Ibrahim CEMAL ${ }^{3}$, Semir Bechir Suheil \\ GAOUAR $^{1}$
}

Received July 18, 2019; accepted December 27, 2019.

Delo je prispelo 18. julija 2019, sprejeto 27. decembra 2019.

\begin{abstract}
Assessment of genetic diversity of Turkish and Algerian native sheep breeds

Abstract: In Algeria and Turkey, the sheep production systems are based on the under extensive rural conditions and their genetic management has led to increased homozygosity and hence productivity loss. The identification of inter-breed and intra-breed genetic diversity plays a key role in the shaping of conservation and breeding programs. The present study was conducted to investigate the genetic diversity of native sheep breeds reared in Turkey and Algeria. A total of 240 animals from four Algerian (Hamra, Ouled Djellal, Sidaou, and Tazegzawt) and four Turkish (White Karaman, South Karaman, Karacabey Merino, and Kivırcık) native sheep breeds were genotyped with fourteen microsatellite markers recommended by FAO. A total of 340 alleles were detected from fourteen markers studied. All the eight breeds exhibited moderate to high levels of genetic diversity, with a slight superiority of the Algerian sheep breeds. Overall FIS value was low, but highly significant $(p<0.001)$. It may have been due to the high inbreeding within the population. The mean global coefficient of gene differentiation (GST) showed that approximately $94.0 \%$ of the genetic variation was within-population. The highest number of private alleles with a frequency above $5 \%$ was observed in Ouled Djellal sheep. Structure analysis of populations studied revealed the most appropriate $\mathrm{K}$ with four genetic clusters. As the result, the dendrogram showed that the Algerian sheep breeds were completely separated from the Turkish sheep breeds furthermore the Bayesian clustering revealed a high level of admixture, especially in Algerian sheep populations.

Key words: small ruminants; native sheep breeds; genetic diversity; microsatellite; genetic distances
\end{abstract}

Pregled genetske pestrosti turških in alžirskih avtohotnih populacij ovac

Izvleček: Sistemi reje ovac v Alžiriji in Turčiji temeljijo na ekstenzivni kmečki reji, upravljanje s temi populacijami pa je privedlo do povečanja homozigotnosti in s tem do poslabšanja proizvodnih lastnosti. Ocena medpasemske in znotrajpasemske genske pestrosti igra ključno vlogo pri oblikovanju programov za ohranjanje teh pasem. Pričujoča študija je bila izvedena $\mathrm{z}$ namenom raziskovanja genske pestrosti avtohtonih pasem ovac v Turčiji in v Alžiriji. Skupno 240 živali štirih alžirskih (hamra, ouled djellal, sidaou in tazegzawt) in štirih turških (white karaman, south karaman, karacabey merino in kıvırcık) pasem je bilo genotipiziranih s štirinajstimi mikrosatelitnimi markerji, ki jih priporoča FAO. Na štirinajstih analiziranih markerskih lokusih je bilo zabeleženih 340 alelov. Vseh osem pasem je imelo zmerno do visoko stopnjo genske pestrosti z rahlo prevlado alžirskih pasem ovac. Skupna vrednost FIS je bila nizka, vendar statistično značilna $(p<0,001)$. To je verjetno posledica visokega inbridinga v populaciji. Povprečni globalni koeficient diferenciacije genov (GST) je pokazal, da je približno 94,0 \% genske pestrosti znotraj populacije. Največ privatnih alelov s pogostostjo nad $5 \%$ je bilo ugotovljenih pri ovcah pasme ouled djellal. Analiza strukture populacij je pokazala, da je K, ki predvideva štiri genetske klastre najprimernejši. Dendrogram, ki je rezultat študije, je pokazal, da so alžirske pasme ovac popolnoma ločene od turških, poleg tega pa je Bayesovo klastriranje pokazalo visoko stopnjo križanja, zlasti v alžirskih populacijah ovac.

Ključne besede: drobnica; avtohtone pasme ovac; genska pestrost; mikrosateliti; genetske distance

1 University of Tlemcen, Department of Biology, Laboratory of Physiopathology and Biochemistry of Nutrition, Algeria

2 Corresponding author, e-mail: ameurabdelkader@gmail.com

3 Adnan Menderes University, Faculty of Agriculture, Department of Animal Science, Aydın, Turkey 


\section{INTRODUCTION}

Domestic sheep (Ovis aries) has been a very important farm animal species for the people economically and culturally since its domestication time around the world (Ryder, 1983). Algeria and Turkey are endowed with diverse farm animal genetic resources including the sheep breeds they are favored by the different climates existed and vegetation, which has since generated a very specific sheep breeding practice. The majority of the sheep population of Turkey and Algeria is composed of multipurpose native breed producing meat, milk, and wool. According to Turkish Statistics Agency, there are 31.2 million sheep heads distributed among twenty sheep breeds have been officially registered while Algeria has a large local sheep population with around 28 million head (Faostat, 2016), the latter contains twelve local ovine breeds with very different phenotypic characteristics (Ameur Ameur et al., 2017).

Turkey has a great genetic diversity that can be characterized by numerous sheep breeds are categorized into four main groups: Fat-tailed, thin-tailed, crossbreeds and extinct breeds (Yilmaz et al., 2013). South Karaman sheep breed, which is one of these breeds and especially raised in the Taurus Mountains located in the Mediterranean region, is a fat tail native sheep breed. It was reported that the hides of this breed, which is very similar to the Karagül breed, could be used in making inner fur because of having a curly pattern of fleece (Ertuğrul et al., 2009; Kiraz et al., 2014). White Karaman sheep breed is the most commonly used breed in central Anatolia in Turkey for lamb production, with a population of around 16.000,000 it makes up more than $50 \%$ of the national sheep herd (TUIK, 2018). Kivirclk and Karacabey Merino sheep breeds are especially raised in western part of Turkey are known for their meat quality, wool, and meat production (Öner et al., 2014; Yilmaz et al., 2011, Karaca et al., 2009). Karacabey Merino was developed by crossbreeding of Kivırcık and German Black Head Mutton (Yalcın, 1986).

Algerian domestic sheep breeds were classified according to many different methods such as phenotypic data, morphological and molecular descriptions throughout history (Chelig, 1992; Djaout et al., 2017). The Ouled Djellal breed (white Arabian breed), which constitutes more than half of the Algerian sheep population and is widely raised in Algeria. This breed has a good body conformation, has a high level of adaptability to different climatic conditions (Chelig, 1992; Djaout et al., 2017). The Hamra sheep breed known as Deghma is a very important sheep breed for meat tenderness in Algeria (Chelig, 1992; Djaout et al., 2017). The Sidaou breed, known as Targuia, is raised in the Sahara between Libya-Niger and southern part of Algeria with several more than one million head (Chelig, 1992; Djaout et al., 2017). Tazegzawt sheep breed which is constituted $0.02 \%$ of the total population raised in Kabyle and Ham in the region of Mechria (Chelig, 1992; Moulla, 2015; Djaout et al., 2017). In recent years, nonsystematic cross-breeding practices and changes in consumer habits have triggered a quantitative reduction of this breed and quickly faced the risk of extinction threat (Moulla, 2015).

Autosomal microsatellites are a well-known effective and powerful tool to investigate genetic structure and diversity have been widely used in sheep breeds, in all over the world, for Turkish sheep breeds (Koban, 2004; Gutiérrez-Gil et al., 2007; Yllmaz and Karaca, 2012; Yilmaz et al.; 2013; Cemal et al., 2013; Yilmaz et al., 2014) and for the Algerian sheep breeds (Gaouar et al., 2014; Gaouar et al.,2015; Gaouar et al.,2016a; Ghernouti et al., 2017; Ameur Ameur et al., 2018).

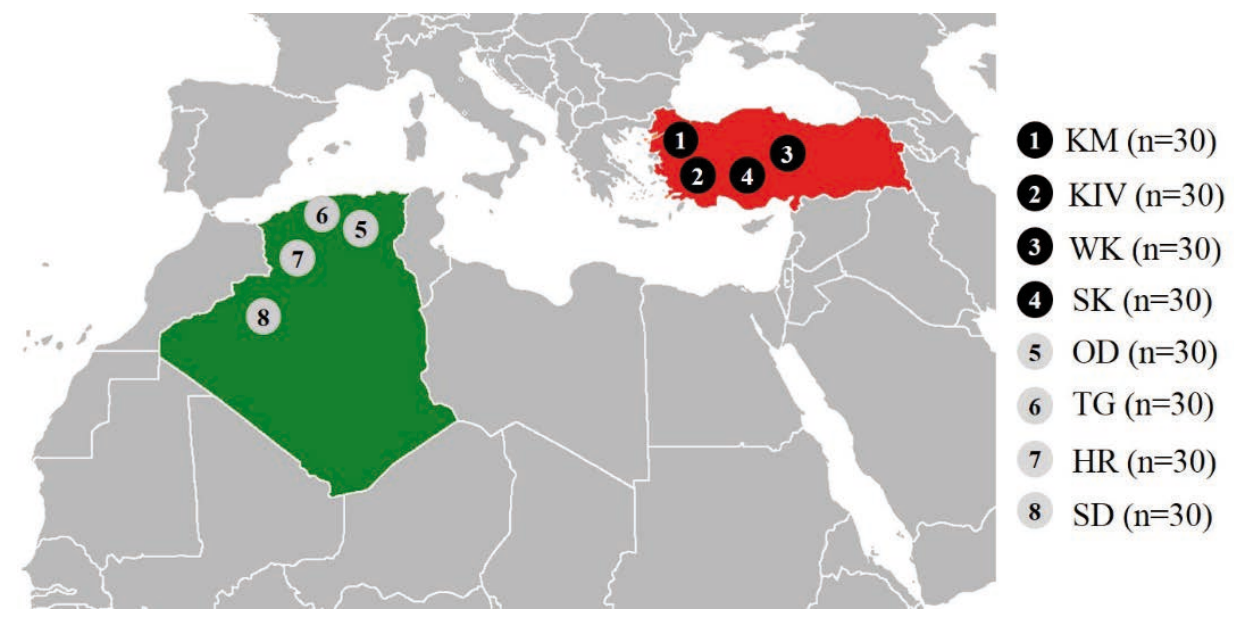

Figure 1: Geographical location of Algeria and Turkish sheep breeds WK: White Karaman, SK: South Karaman, KM: Karacabey Merino, KIV: Kıvırcık, HR: Hamra, OD: Ouled Djellal, SD: Sidaou, TG: Tazegzawt 
The first step for a well-structured and sustainable animal breeding and conservation program is to reveal detailed information on intra and inter-breed genetic diversity. This situation indicates how important it is to reveal the genetic structure of breeds. The objective of the present study was to determine genetic diversity and population structure of different native sheep breeds raised in two different countries.

\section{MATERIALS AND METHODS}

\subsection{ANIMAL MATERIAL AND DNA ISOLATION}

Blood samples were obtained from 240 sheep, which consist of Hamra (30), Ouled Djellal (30), Sidaou (30), Tazegzawt (30) raised in Algeria and White Karaman (30), South Karaman (30), Karacabey Merino (30) and Kivırcık sheep (30) breeds raised in Turkey (Figure 1).

\subsection{SAMPLING METHOD AND DNA ISOLATION}

Blood samples were obtained from 240 head sheep. Blood samples were collected from Vena jugularis into tubes containing K3-EDTA as anticoagulant and stored at $-20{ }^{\circ} \mathrm{C}$ until DNA extraction. DNA was extracted by using the salting-out technique reported by Miller et al. (1988) and Montgomery and Sise (1990). NanoDrop 2000 (Thermo Scientific, Waltham, MA) spectropho- tometer device was used to determinate the quality and quantity of DNA samples.

\subsection{PCR AND FRAGMENT ANALYSIS}

Fourteen microsatellite markers labeled with a fluorescent dye (D2, D3, and D4) were used according to the recommendation of FAO (2011). Two multiplex groups were created according to the fragment length of microsatellites. Touchdown PCR protocols reported by Hecker and Roux, (1996) were used for the amplification of specific genomic regions (Table 1). The total volume of the amplification mixture amounted to $25 \mu \mathrm{L}$. Amplification mixture contained $0.1 \mu \mathrm{M}$ /each primer, $0.2 \mathrm{mM}$ dNTPs (Applied Biological Materials Inc., Canada), 2.0 $\mathrm{mM} \mathrm{MgCl} 2$, $1 \mathrm{X}$ PCR buffer, $1 \mathrm{U}$ of Taq DNA polymerase (Applied Biological Materials Inc.. Canada) and 50 ng genomic DNA. Capillary electrophoresis was used for the separation of the PCR fragments labeled with fluorescent dye in the Beckman Coulter GeXP genetic analyzer (Beckman Coulter. Inc. USA).GenomeLab ${ }^{\mathrm{Tm}}$ DNA Size Standard Kit 400 was used for the determination of fragment size.

\subsection{STATISTICAL ANALYSIS}

The polymorphism statistics such as number of alleles per locus $(\mathrm{Na})$, mean number of alleles $(\mathrm{MNa})$, effective number of alleles $(\mathrm{Ne})$, observed heterozygosity

Table 1: Thermal cycling conditions according to Touchdown PCR

\begin{tabular}{|c|c|c|c|c|c|c|c|}
\hline Loci (Dye) & $\begin{array}{l}\text { Multiplex } \\
\text { group }\end{array}$ & $\begin{array}{l}\text { First } \\
\text { denaturation }\end{array}$ & Denaturation & Annealing & Extension & Cycle & Final extension \\
\hline OarFCB193 (D3) & \multirow[t]{6}{*}{1} & \multirow{6}{*}{$\begin{array}{l}95^{\circ} \mathrm{C} \\
(5 \mathrm{~min})\end{array}$} & \multirow{6}{*}{$\begin{array}{l}95^{\circ} \mathrm{C} \\
(40 \mathrm{sec})\end{array}$} & \multirow{6}{*}{$\begin{array}{l}63-54{ }^{\circ} \mathrm{C} \\
(40 \mathrm{sec})\end{array}$} & \multirow{6}{*}{$\begin{array}{l}72^{\circ} \mathrm{C} \\
(60 \mathrm{sec})\end{array}$} & \multirow[t]{6}{*}{40} & \multirow{6}{*}{$\begin{array}{l}72^{\circ} \mathrm{C} \\
(10 \mathrm{~min})\end{array}$} \\
\hline OarFCB304 (D3) & & & & & & & \\
\hline INRA0023 (D3) & & & & & & & \\
\hline OarCP34 (D4) & & & & & & & \\
\hline D5S2 (D4) & & & & & & & \\
\hline BM1818 (D4) & & & & & & & \\
\hline BM8125 (D3) & \multirow[t]{8}{*}{2} & \multirow{8}{*}{$\begin{array}{l}95^{\circ} \mathrm{C} \\
(5 \mathrm{~min})\end{array}$} & \multirow{8}{*}{$\begin{array}{l}95^{\circ} \mathrm{C} \\
(40 \mathrm{sec})\end{array}$} & \multirow{8}{*}{$\begin{array}{l}60-50{ }^{\circ} \mathrm{C} \\
(40 \mathrm{sec})\end{array}$} & \multirow{8}{*}{$\begin{array}{l}72^{\circ} \mathrm{C} \\
(60 \mathrm{sec})\end{array}$} & \multirow[t]{8}{*}{34} & \multirow{8}{*}{$\begin{array}{l}72{ }^{\circ} \mathrm{C} \\
(10 \mathrm{~min})\end{array}$} \\
\hline McM0527 (D3) & & & & & & & \\
\hline CSRD0247 (D3) & & & & & & & \\
\hline OarFCB128 (D2) & & & & & & & \\
\hline BM1329 (D2) & & & & & & & \\
\hline HSC (D2) & & & & & & & \\
\hline OarJMP29 (D4) & & & & & & & \\
\hline MAF214 (D4) & & & & & & & \\
\hline
\end{tabular}


(Ho), expected heterozygosity (He), Wright's F-statistics $\left(\mathrm{F}_{\mathrm{IT}}, \mathrm{F}_{\mathrm{IS}}, \mathrm{F}_{\mathrm{ST}}\right)$, Hardy-Weinberg equilibrium and Principal component analysis (PCoA) was performed using the software GENALEX (Peakall \& Smouse, 2006) were calculated using GenAlEx (Peakall and Smouse, 2012). Polymorphic information content (PIC) and null allele frequencies were calculated using CERVUS 3.0.3 (Marshall, 1998). Populations 1.2.32 (Langella, 1999) and FigTree 1.4.2. (Rambout, 2006) software was used to generate neighbor-joining (NJ) tree phylogenetic tree between breeds according to Nei's Da distance matrix (Nei et al., 1983). Robustness of the dendrogram topology was tested by bootstrap resampling $(n=1000)$. FSTAT version 2.9.3 software (Goudet, 2001) was used to obtain values belong to genetic diversity statistics such as Nei's gene diversity $\left(\mathrm{H}_{\mathrm{T}}\right)$, diversity between breeds $\left(\mathrm{D}_{\mathrm{ST}}\right)$, and coefficient of gene differentiation $\left(\mathrm{G}_{\mathrm{ST}}\right)$. Analysis of molecular variance (AMOVA) was performed using the ARLEQUIN v3.5.2.2 (Excoffier and Lischer, 2010). The STRUCTURE software was used to analyze population structure using independent allele frequencies and an admixture model (burn of 20.000, followed by 100.000 MCMC iterations with 20 replicate runs for each K) (Pritchard et al., 2000). The appropriate number of clusters was identified using $\Delta \mathrm{K}$ values ( $\mathrm{K}=2$ to 8 ) that expressing the proportion of alteration in the logarithmic probability $\operatorname{Pr}(\mathrm{X} \mid \mathrm{K})$ (Evanno et al., 2005). The most suitable $\mathrm{K}$ value was determined according to $\Delta \mathrm{K}$ value calculated by the STRUCTURE harvester program (Earl and Vonholdt, 2012). The CLUMPAK program reported by Kopelman et al. (2015) was used to find the best alignment from the obtained STRUCTURE results.

\section{RESULTS}

In this study, a total of 340 alleles were identified from fourteen microsatellites used in the present study. Molecular genetic statistical parameters obtained from the fourteen microsatellites used was given in Table 2.

The number of alleles ranged from 17 (OarCP34, D5S2) to 32 (CSRD0247), while the average number of effective alleles was 10.99. Observed heterozygosity (Ho) values varied from 0.67 (OarFCB304) to 0.85 (OarCP34). PIC values were found to be between 0.87 and $0.93 . \mathrm{F}_{\text {IS }}$ values that use the local gene pool as a reference point were obtained as positive in thirteen of fourteen microsatellites. The $\mathrm{F}_{\mathrm{IT}}$ value expressing general heterozygosity loss was higher in BM1329 (0.254) locus than the other. $\mathrm{F}_{\mathrm{ST}}$ described as an indicator of genetic variation among individuals within the population was observed varied from OarJMP29 (0.041) to BM1329 (0.107) with a mean of 0.068 . Mean value of $\mathrm{D}_{\mathrm{ST}}$ indicating genetic diversity between breeds, $\mathrm{G}_{\mathrm{ST}}$, which is an important indicator of

Table 2: Genetic polymorphism parameters of the fourteen investigated loci in sheep breeds studied

\begin{tabular}{|c|c|c|c|c|c|c|c|c|c|c|c|c|c|c|}
\hline Locus & $\mathrm{N}$ & $\mathrm{Na}$ & $\mathrm{Ne}$ & PIC & Ho & $\mathrm{He}$ & $\mathrm{F}_{\mathrm{IS}}{ }^{*}$ & $\mathrm{~F}_{\mathrm{IT}}^{*}$ & $\mathrm{~F}_{\mathrm{ST}}{ }^{*}$ & $\mathrm{D}_{\mathrm{ST}}$ & $\mathrm{G}_{\mathrm{ST}}$ & $\mathrm{H}_{\mathrm{T}}$ & HWE & F(Null) \\
\hline OarFCB304 & 237 & 25 & 8.22 & 0.87 & 0.67 & 0.88 & $0.172^{* * *}$ & $0.252^{* * *}$ & $0.096^{* * *}$ & 0.074 & 0.084 & 0.88 & $* * *$ & 0.134 \\
\hline OarFCB193 & 239 & 23 & 9.17 & 0.89 & 0.80 & 0.89 & $0.066^{* *}$ & $0.105^{* * *}$ & $0.042^{* * *}$ & 0.033 & 0.036 & 0.89 & $* * *$ & 0.053 \\
\hline BM1818 & 234 & 28 & 14.17 & 0.93 & 0.83 & 0.93 & $0.047^{*}$ & $0.118^{* * *}$ & $0.075^{* * *}$ & 0.061 & 0.065 & 0.93 & $* * *$ & 0.059 \\
\hline INRA0132 & 240 & 21 & 11.92 & 0.91 & 0.82 & 0.92 & $0.052^{*}$ & $0.113^{* * *}$ & $0.064^{* * *}$ & 0.052 & 0.056 & 0.92 & $* * *$ & 0.057 \\
\hline OarCP34 & 239 & 17 & 7.68 & 0.86 & 0.85 & 0.87 & $-0.029^{\mathrm{ns}}$ & $0.027^{\mathrm{ns}}$ & $0.055^{* * *}$ & 0.042 & 0.049 & 0.87 & $* * *$ & 0.008 \\
\hline D5S2 & 207 & 17 & 8.19 & 0.87 & 0.73 & 0.88 & $0.109^{* *}$ & $0.181^{* * *}$ & $0.080^{* * *}$ & 0.061 & 0.069 & 0.88 & $* * *$ & 0.092 \\
\hline CSRD0247 & 230 & 32 & 13.21 & 0.92 & 0.76 & 0.92 & $0.120^{* * *}$ & $0.186^{* * *}$ & $0.075^{* * *}$ & 0.062 & 0.067 & 0.93 & $* * *$ & 0.103 \\
\hline MCM0527 & 232 & 20 & 9.59 & 0.89 & 0.68 & 0.90 & $0.207^{* * *}$ & $0.252^{* * *}$ & $0.056^{* * *}$ & 0.044 & 0.049 & 0.90 & $* * *$ & 0.140 \\
\hline BM8125 & 240 & 20 & 12.70 & 0.92 & 0.78 & 0.92 & $0.094^{* * *}$ & $0.169^{* * *}$ & $0.083^{* * *}$ & 0.068 & 0.074 & 0.92 & $* * *$ & 0.083 \\
\hline HSC & 231 & 24 & 14.48 & 0.93 & 0.72 & 0.93 & $0.191^{* * *}$ & $0.230^{* * *}$ & $0.048^{* * *}$ & 0.039 & 0.042 & 0.93 & $* * *$ & 0.122 \\
\hline BM1329 & 237 & 31 & 14.13 & 0.93 & 0.70 & 0.93 & $0.164^{* * *}$ & $0.254^{* * *}$ & $0.107^{* * *}$ & 0.088 & 0.094 & 0.93 & $* * *$ & 0.137 \\
\hline OarFCB128 & 240 & 22 & 10.22 & 0.90 & 0.76 & 0.90 & $0.116^{* * *}$ & $0.162^{* * *}$ & $0.052^{* * *}$ & 0.041 & 0.046 & 0.90 & $* * *$ & 0.086 \\
\hline OarJMP29 & 240 & 31 & 11.20 & 0.91 & 0.81 & 0.91 & $0.081^{* * *}$ & $0.119^{* * *}$ & $0.041^{* * *}$ & 0.033 & 0.036 & 0.91 & $* * *$ & 0.058 \\
\hline MAF214 & 240 & 29 & 8.92 & 0.88 & 0.77 & 0.89 & $0.071^{*}$ & $0.142^{* * *}$ & $0.076^{* * *}$ & 0.060 & 0.068 & 0.89 & $* * *$ & 0.077 \\
\hline Mean & & 24.29 & 10.99 & 0.90 & 0.76 & 0.90 & 0.104 & 0.165 & 0.068 & 0.054 & 0.060 & 0.91 & & \\
\hline
\end{tabular}

$\mathrm{N}$ : Number of genotyped individuals, Na: number of alleles, Ne: effective number of alleles, PIC: polymorphic information content, $\mathrm{F}_{\mathrm{IT}}, \mathrm{F}_{\mathrm{IS}}, \mathrm{F}_{\mathrm{ST}}$ : Wright's F-statistics, Ho: observed heterozygosity, He: expected heterozygosity, HWE: Hardy-Weinberg Equilibrium, F(Null): null allele frequency, $\mathrm{H}_{\mathrm{T}}$ : Nei's gene diversity, $\mathrm{D}_{\mathrm{ST}}$ : the diversity between breeds, $\mathrm{G}_{\mathrm{ST}}$ : coefficient of gene differentiation, ${ }^{*}$ : Wright's statistics according to Weir and Cockerham (1984), ${ }^{*}: p<0.05,{ }^{* *}: p<0.01,{ }^{* * * *}: p<0.001$ 
Table 3: Genetic polymorphism parameters according to studied Turkish and Algerian sheep breeds across 14 loci

\begin{tabular}{|c|c|c|c|c|c|c|c|c|}
\hline \multirow[b]{2}{*}{ Breeds } & \multirow[b]{2}{*}{ MNA } & \multicolumn{2}{|c|}{ Mean Heterozigosity } & \multirow[b]{2}{*}{$\mathrm{F}_{\mathrm{IS}}$} & \multirow[b]{2}{*}{ HWE } & \multicolumn{3}{|l|}{ NPA } \\
\hline & & Ho (SE) & $\mathrm{He}(\mathrm{SE})$ & & & $\begin{array}{l}\text { Freq. } \\
\geq 5 \%\end{array}$ & $\begin{array}{l}\text { Freq. } \\
<5 \%\end{array}$ & Total \\
\hline WK & 9.93 & $0.78(0.040)$ & $0.80(0.016)$ & $0.047^{\mathrm{ns}}$ & 5 & 5 & 3 & 8 \\
\hline KIV & 9.57 & $0.58(0.056)$ & $0.81(0.012)$ & $0.326^{* * *}$ & 9 & 3 & 1 & 4 \\
\hline KM & 10.21 & $0.67(0.058)$ & $0.76(0.030)$ & $0.114^{* * *}$ & 11 & 1 & 5 & 6 \\
\hline SK & 9.57 & $0.72(0.063)$ & $0.74(0.059)$ & $0.055^{* *}$ & 2 & 2 & 3 & 5 \\
\hline HR & 14.71 & $0.84(0.023)$ & $0.89(0.006)$ & $0.055^{* * *}$ & 8 & 1 & 5 & 6 \\
\hline OD & 17.00 & $0.83(0.022)$ & $0.90(0.005)$ & $0.075^{* * *}$ & 5 & - & 17 & 17 \\
\hline SD & 13.86 & $0.82(0.028)$ & $0.87(0.010)$ & $0.025^{\mathrm{ns}}$ & 4 & 1 & 7 & 8 \\
\hline TG & 15.07 & $0.83(0.028)$ & $0.86(0.014)$ & $0.038^{*}$ & 7 & 1 & 11 & 12 \\
\hline
\end{tabular}

WK: White Karaman, SK: South Karaman, KM: Karacabey Merino, KIV: Kivırcık, HR: Hamra, OD: Ouled djellal, SD: Sidaou, TG: Tazegzawt, MNA: number of alleles, Ho: observed heterozygosity. He: expected heterozygosity, HWE: number of loci not in the Hardy-Weinberg equilibrium $(p<0.05)$, NPA: private alleles, within-breed, $\mathrm{F}_{\mathrm{IS}}$ : heterozygote deficiency, ${ }^{*}: p<0.05,{ }^{* *}: p<0.01,{ }^{* * *}: p<0.001$

the relative magnitude of genetic differentiation, and $\mathrm{H}_{\mathrm{T}}$ described as total genetic diversity, values were found as $0.054,0.060$ and 0.91 , respectively. Microsatellite loci genotyped in the present study were tested using the $\chi^{2}$ test in terms of compliance with HWE. All fourteen loci and SK) to 17.00 (OD). The highest expected heterozygosity was observed in OD (0.90) sheep breed reared in Algeria. All the studied breeds showed positive $\mathrm{F}_{\mathrm{IS}}$ values. Although a total of 66 private alleles have been identified in all breeds studied, only fourteen of them have a fre-

Table 4: AMOVA of the eight sheep breeds genotyped with fourteen microsatellite markers

\begin{tabular}{lrrrrr}
\hline Variation Sources & DF & SS & VC & PV (\%) & FI \\
\hline Among population & 7 & 204.88 & $0.3893 \mathrm{Va}$ & 6.71 & $\mathrm{~F}_{\text {IS }}=0.092$ \\
Among individuals within populations & 232 & 1370.53 & $0.4964 \mathrm{Vb}$ & 8.56 & $\mathrm{~F}_{\text {ST }}=0.067$ \\
Within individuals & 240 & 1179.50 & $4.9145 \mathrm{Vc}$ & 84.73 & $\mathrm{~F}_{\text {IT }}=0.153$ \\
\hline Total & 479 & 2754.91 & 5.800 & & \\
\hline
\end{tabular}

DF: degree of freedom, SS: sum of square, VC: variance components, PV: percentage of variance, FI: fixation index

deviated from the HWE $(p<0.001)$. Null allele frequency belonging to microsatellite loci used were found to be below $20 \%$. The results of genetic diversity statistics for each breed are summarized in Table 3 .

The mean number of alleles varied from 9.57 (KIV

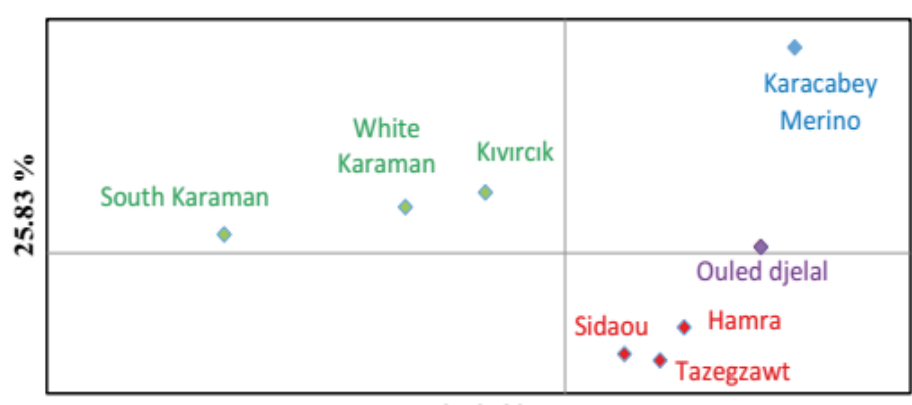

$35.37 \%$

Figure 2: Principal component analysis. Plot of the first (PC1: $\mathrm{X}$ axis) and second (PC2: Y axis) principal components for 8 sheep populations. quency greater than $5 \%$. Analysis of Molecular Variance (AMOVA), which is a method to detect population differentiation utilizing molecular markers, was performed to detect genetic variation between individuals and populations (Table 4).

It was revealed $84.73 \%$ of the total variance was found within individuals while $8.56 \%$ among individuals within populations and $6.71 \%$ among the population.

In the PCA analysis (Figure 2) of the Nei's genetic distance, the first two axes represent $35.38 \%$ and $25.83 \%$ of the total genetic variability, respectively. The phylogenetic network of eight sheep breeds (Figure 3) confirmed and complemented the PCA analysis results. Four cluster belonging to eight breeds studied was revealed in dendrogram based on Nei's Da distance matrix. The first cluster consisted of WK, 


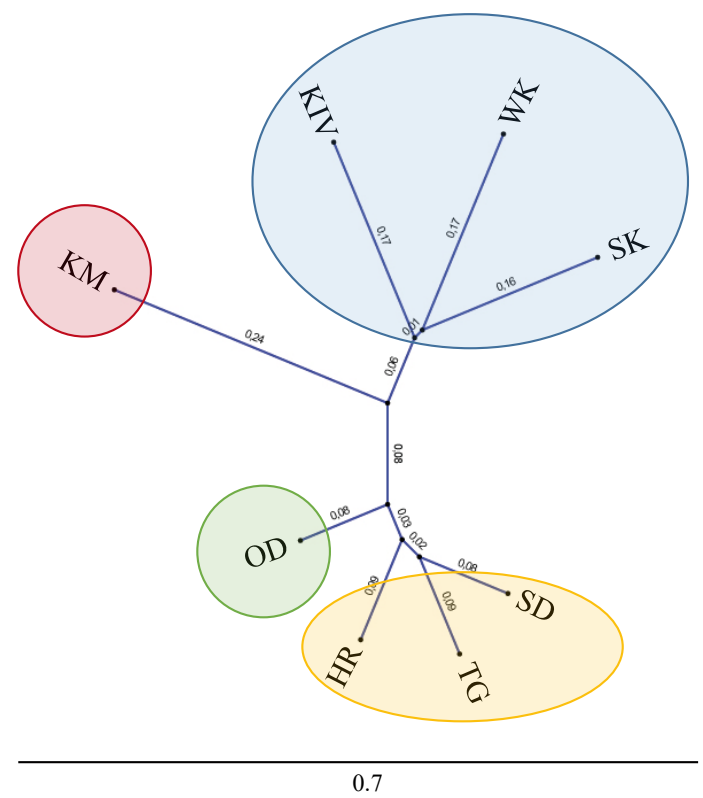

Figure 3: Dendrogram based on Nei's Da distance matrix in studied sheep breeds (bootstrap resampling methodology (1000 replicates)) (WK: White Karaman, SK: South Karaman, KM: Karacabey Merino, KIV: Kivircık, HR: Hamra, OD: Ouled djellal, SD: Sidaou, TG: Tazegzawt)

SK and KIV, the second cluster was formed by KM sheep breed raised in Turkey, the third cluster was formed by OD sheep breed and fourth cluster was formed by HR, TG and SD sheep breeds sampled from Algeria.

The results of the Population structure analysis containing different numbers of clustering $(\mathrm{K}=2-8)$ and performed to determine the population structure of the studied breeds are given in Figure 4.

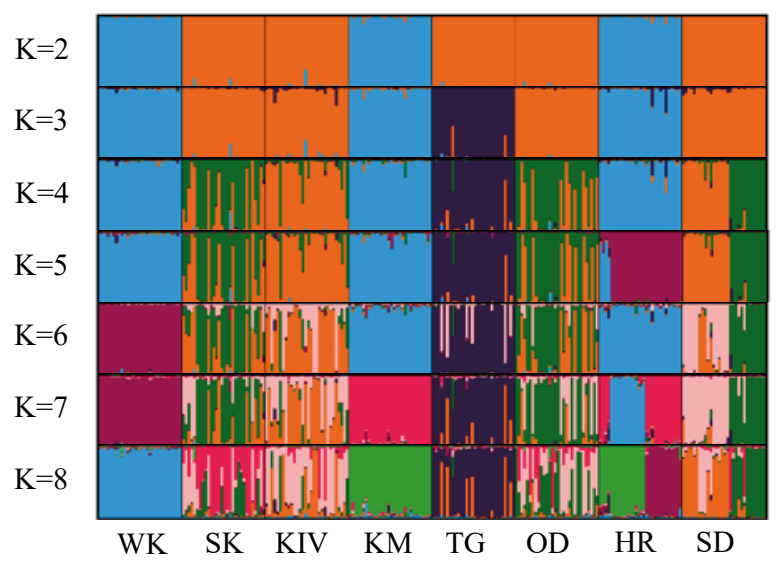

Figure 4: Estimation of the population structure with different K values (WK: White Karaman, SK: South Karaman, KM: Karacabey Merino, KIV: Kivircık, HR: Hamra, OD: Ouled Djellal, SD: Sidaou, TG: Tazegzawt)
Table 5: Estimated posterior probabilities $[\operatorname{Ln} \operatorname{Pr}(\mathrm{X} \mid \mathrm{K})]$ for different numbers of inferred clusters $(\mathrm{K})$ and $\Delta \mathrm{K}$ statistic

\begin{tabular}{lll}
\hline $\mathrm{K}$ & Mean $\operatorname{LnP}(\mathrm{K})$ & $\Delta \mathrm{K}$ \\
\hline 2 & $-16.760,605$ & - \\
3 & $-16.232,850$ & 3.7415 \\
4 & $-16.025,320$ & 6.1730 \\
5 & $-16.209,625$ & 0.5631 \\
6 & $-15.647,060$ & 3.9293 \\
7 & $-15.638,650$ & 2.5657 \\
8 & $-16.353,680$ & - \\
\hline
\end{tabular}

To present the suitable cluster number $(\mathrm{K})$ in structure analysis results were given in Table 5.

The results obtained from the STRUCTURE analysis were similar to the dendrogram drawn according to Nei's Da distance matrix (Nei et al., 1983) as expected. It is seen that the optimal number of groups was 4 considering the value of $\Delta \mathrm{K}$ obtained by the method reported by Evanno et al. (2005).

\section{DISCUSSION}

Today, conservation of farm animal species and the determination of the genetic diversity is currently on the agenda of animal breeders. In this context, conservation activities and characterization of genetic diversity for animal genetic resources have become very important phenomena in all over the world. Genetic variation needed for genetic improvement of domestic animals is a basic requirement for animal breeding (Askari et al., 2011).

Mean number of alleles and polymorphic information content values observed in the present study were higher than values obtained from the other sheep breeds (Yilmaz et al., 2015; Guang-Xin et al., 2016; Kırıkçı et al., 2018). This situation can be regarded as an important indicator of high genetic diversity in sheep populations studied.

$\mathrm{F}_{\mathrm{IS}}$ values, which is a measure of the deviation of genotypic frequencies from panmixia in populations in terms of heterozygous deficiency or excess, showed that loss of heterozygosity at just one microsatellite locus (OarCP34). The value of overall $\mathrm{F}_{\mathrm{IS}}$ was low, but highly significant $(p<0.001)$. It may have been due to the high inbreeding within the population. The local inbreeding coefficient $\left(\mathrm{F}_{\mathrm{IS}}\right)$ values, which is used the local gene pool as the point of reference, was low but highly significant $(p<0.01)$ except OarCP34.

Similar findings have been found in previous experiments, conducted in different sheep breeds (Yilmaz et al., 2015). Overall $F_{S T}$ value indicated that a moderate 
genetic drift occurred in populations. It can be said that this situation is an expected finding given that populations are reared under extensive conditions and are mated freely.

The global $\mathrm{G}_{\mathrm{ST}}$ value showed that $94.00 \%$ of the total genetic variation can be explained by genetic differences among individuals. It can be accepted that the overall genetic diversity value (DST) obtained from the present study was an indication that the inter-population variability is not high. This finding supported the previously mentioned FST and GST results.

Overall $\mathrm{H}_{\mathrm{T}}$ described as Nei's gene diversity value was 0.91 which was higher than the values obtained from Algerian native sheep breeds (Ameur Ameur et al., 2018), Turkish native sheep breeds (Yilmaz et al., 2015) and Albanian native sheep breeds (Hoda and Marsan, 2012) This finding supported $\mathrm{Na}$ and PIC values is an indication that goats have a high genetic diversity of populations studied.

The Hardy-Weinberg equilibrium (HWE), which is stated that allele and genotype frequencies in a population will remain constant from generation to generation in the absence of other evolutionary mechanisms, was analyzed using $\chi^{2}$ test. Test results showed that allele distributions of all studied loci deviated from HardyWeinberg equilibrium. This is an expected finding due to the intensive selection studies conducted in the studied populations for long years.

Null allele, which was first introduced by Paetkau and Strobeck (1995), causes to misreading of the microsatellite peaks. It has been reported by Dakin and Avise (2004) that null allele frequencies below 0.20 have no significant effect on molecular genetic studies performed with microsatellites. When the null allele frequencies obtained are examined, it is seen that the null allele frequency values of fourteen microsatellites to be studied are below 0.20 . Taking this value into consideration, it has been demonstrated that working locus can be used safely in genetic diversity.

In the present study, the calculated $\mathrm{MNa}$ values belonging to Algerian sheep populations studied were found to be higher than the values stated in some studies on domestic and foreign breeds (Gaouar et al., 2016b; Loukovitis et al., 2016; Naqvi et al., 2017) but MNa values observed in Turkish sheep breeds were lower than those of native sheep breeds raised in Tunisia (Sassi-Zaidy et al., 2016). This is thought to be due to the difference in the number of microsatellites and sampling methodology used in this study. FIS value, defined as the inbreeding coefficient, indicated that there is no loss of heterozygosity in populations. Deviations from the Hardy-Weinberg equilibrium should be regarded as a natural consequence of the intensive animal breeding activities that have been practiced in the populations for many years. Although the number of private alleles defined as the source of genetic diversity which has a frequency above $5 \%$ are limited, it can be said that they have sufficient efficiency to identify populations studied.

It is seen that the essential genetic diversity is realized within individuals when the results of the analysis of molecular variance (AMOVA) are examined. Fixation index values give an idea in terms of the inbreeding coefficient and population differences. Analysis of molecular variance (AMOVA) results pointed out that these eight native sheep breeds can be differentiated weakly. The $\mathrm{F}_{\text {ST }}$ value obtained from the AMOVA analysis was parallel to the $\mathrm{G}_{\mathrm{ST}}$ value. This finding proves that most of the genetic diversity is caused by the difference between individuals in the present study.

It was noticed that there were four clusters when the dendrogram was examined. Dendrogram, which is showed the position of the Turkish sheep breeds in the present study was different from the findings obtained from the study conducted on the same breeds by Yilmaz et al. (2015). It is known that the Karacabey Merino breed was obtained by crossbreeding the sheep breeds of Kivircik reared in the Marmara region and German Black Head Mutton (Sezenler and Özder, 2009). It has a large number of local Kivircik form that is adapted to the different regions in Turkey (Öner et al., 2014). Kivircık sheep breed which is used as animal material in the study material is raised in the Aegean region. In the context of this information, it is expected result that these two breeds will take place in different clusters in the obtained dendrogram.

STRUCTURE results showed a low level of differentiation and a high level of admixture, especially in Algerian sheep populations. The value of $\Delta \mathrm{K}$ obtained by the method reported by Evanno et al. (2005) shows that the optimal number of groups is four as in the dendrogram. This revealed that STRUCTURE analysis and dendrogram results supported each other. It can be said that there was a high gene flow between Algerian sheep populations when examined the results obtaoined by CLUMPACK software.

\section{CONCLUSION}

Domestic sheep reared all over the world, are raised for meat, milk, or fiber production, or conservation purposes. Non-systematic cross-breeding practices applied to increase the production capabilities of domestic animals carried out by breeders are among the main problems of animal husbandry in North African countries as in Turkey (Karaca et al., 2009). This type of practice leads 
to one of the major threats such as the disappearance of local genetic diversity (Herold et al., 2012).

The present study, which was carried out for the first time, was not described any genetic similarities between Algeria and Turkey sheep breeds. However, the result shows that populations studied have a low level of differentiation and a high level of admixture. Results obtained from the present study revealed that Algerian and Turkish sheep breeds have a high genetic variability. While the knowledge of genetic diversity between breeds is important, the benefit of understanding the genetic variation within a population is considerable. There is no research focused on within and between breed genetic variations in Algerian and Turkish sheep breeds. Microsatellites used in the study have a highly accurate identification potency for the genetic diversity of the studied breeds.

In conclusion, the present study has revealed an important knowledge about genetic diversity and the relationship between some sheep breeds raised in Algeria and Turkey. The information obtained in the study has made a significant contribution to future animal genetic conservation and breeding programs.

\section{ACKNOWLEDGMENTS}

We acknowledge Adnan Menderes University Agricultural Biotechnology and Food Safety Application and Research Centre (ADÜ-TARBİYOMER) for providing laboratory facilities to carry out molecular genetic analysis.

\section{CONFLICT OF INTEREST}

The authors declare that they have no conflict of interest.

\section{REFERENCES}

Ameur Ameur, A., Ata, N., Benyoucef, M. T., Djaout, A., Azzi, N., Yilmaz, O., ... Gaouar, S. B. S. (2018). New genetic identification and characterization of 12 Algerian sheep breeds by microsatellite markers. Italian Journal of Animal Science, 17(1), 38-48. https://doi.org/10.1080/182805 1X.2017.1335182

Askari, N., Mohammad, A. M., \& Baghizadeh, A. (2011). ISSR markers for assessing DNA polymorphism and genetic characterization of cattle, goat and sheep populations. Iranian Journal of Biotechnology, 9(3), 222-229.

Cemal, İ., Yılmaz, O., Karaca, O., Binbaş, P., \& Ata, N. (2013). Analysis of genetic diversity in indigenous Çine Çaparı sheep under conservation by microsatellite markers. Kafkas Univ Vet Fak Derg, 19, 383-390.
Chellig, R. (1992). Les « races » ovines algériennes. Editions. Alger: Office des Publications Universitaires.

Dakin, E. E., \& Avise, J. C. (2004). Microsatellite null alleles in parentage analysis. Heredity, 93, 504-509. https://doi.org/10.1038/sj.hdy.6800545

Djaout, A., Afri-Bouzebda, F., Chekal, F., El-Bouyahiaoui, R., Rabhi, A., Boubekeur, A., ... Gaouar, S. B. S. (2017). Biodiversity state of Algerian sheep breeds. Genetics and Biodiversity Journal, 1(1), 1-18.

Earl, D. A., \& vonHoldt, B. M. (2012). STRUCTURE HARVESTER: a website and program for visualizing STRUCTURE output and implementing the Evanno method. Conservation Genetics Resources, 4(2), 359-361. https://doi.org/10.1007/s12686-011-9548-7

Ertuğrul, M., Dellal, G., Soysal, İ., Elmacı, C., Akın, O., Arat, S., ... Yilmaz, O. (2009). Türkiye Yerli Koyun Irklarının Korunması. Uludă̆ Üniversitesi Ziraat Fakültesi Dergisi, 23(2), 97-119.

Evanno, G., Regnaut, S., \& Goudet. (2005). Detecting the number of clusters of individuals using the software STRUCTURE: a simulation study. Mol Ecol. 14, 2611-2620. https://doi.org/10.1111/j.1365-294X.2005.02553.x

Excoffier, L., \& Lischer, H. E. L. (2010). Arlequin suite ver 3.5: a new series of programs to perform population genetics analyses under Linux and Windows. Mol Ecol Resour. 10, 564-567. https://doi.org/10.1111/j.1755-0998.2010.02847.x

FAO. (2011). Molecular Genetic Characterization of Animal Genetic Resources. Rome, Italy: Food and Agricultural Organization of the United Nations.

FAO. (2016). FAOSTAT data. Retrieved from http://www.fao. org/faostat/en/\#data

Gaouar, S. B. S, Lafri, M., Djaout, A., El-Bouyahiaoui, R., Bouri, A., Bouchatal, A., ... Da Silva, A. (2016a). Genome-wide analysis highlights genetic dilution in Algerian sheep. Heredity, 118, 293-301. https://doi.org/10.1038/hdy.2016.86

Gaouar, S. B. S., Kdidi, S., \& Ouragh, L. (2016b). Estimating population structure and genetic diversity of five Moroccan sheep breeds by microsatellite markers. Small Ruminant Research, 144, 23-27. https://doi.org/10.1016/j.smallrumres.2016.07.021

Gaouar, S. B. S., Da Silva, A., Ciani, E., Kdidi, S., Aouissat, M., Dhimi, L., ... Mehtar, N. (2015). Admixture and local breed marginalization threaten Algerian sheep diversity. PLoS One, 10, e0122667. https://doi.org/10.1371/journal. pone. 0122667

Gaouar, S. B. S., Kdidi, S., Tabet Aouel, N., Aït-Yahia, R., Boushaba, N., Aouissat, M., ... Saidi-Mehtar, N. (2014). Genetic admixture of NorthAfrican ovine breeds as revealed by microsatellite loci. Livest Res Rural Dev. 26(7).

Ghernouti, N., Bodinier, N., Ranebi, M., Maftah, D., Petit, D. \& Gaouar, S. B. S., (2017). Control Region of mtDNA identifies three migration events of sheep breeds in Algeria. Small Ruminant Research, 155, 66-71. https://doi.org/10.1016/j. smallrumres.2017.09.003

Goudet, J. (2001). FSTAT (Version 2.9.3.). A Program to Estimate and Test Gene Diversities and Fixation Indices. Lausanne. Switzerland: University of Lausanne.

Guang-Xin, E, Zhong, T., Ma, Y. H., Gao, H. J., He, J. N., Liu, N., ... Huang, Y. F. (2016). Conservation genetics in Chi- 
nese sheep: diversity of fourteen indigenous sheep (Ovis aries) using microsatellite markers. Ecol Evol, 6, 810-817. https://doi.org/10.1002/ece3.1891

Gutiérrez-Gil, B., Uzun, M., Arranz, J. J., San Primitivo, F., Yildiz, S., Cenesiz, M., \& Bayón, Y. (2007). Genetic diversity in Turkish sheep. Acta Agriculturae Scandinavica, Section A - Animal Science, 56(1), 1-7. https://doi.org/10.1080/09064700600641681

Hecker, K. H. \& Roux, K. H. (1996). High and low annealing temperatures increase both specificity and yield in touchdown and stepdown PCR. Biotechniques, 20, 478-485. https://doi.org/10.2144/19962003478

Herold, P., Roessler, R., Willam, A., Momm, H. \& Valle Zárate, A., (2012). Breeding and supply chain systems incorporating local pig breeds for small-scale pig producers in Northwest Vietnam. Livest. Prod. Sci., 129, 63-72. https://doi.org/10.1016/j.livsci.2010.01.004

Hoda, A. \& Marsan, P. A. (2012). Genetic Characterization of Albanian Sheep Breeds by Microsatellite Markers. In M. Caliskan (Ed.), Analysis of Genetic Variation in Animals. London: IntechOpen. https://doi.org/10.5772/34554

Karaca, O., Arık, İ. Z., Biçer, O., Cemal, İ., Yılmaz, O. \& Ulutaş, Z., (2009). Production systems in Turkey's sheep husbandry and strategic suggestions. Türkiye Ulusal Koyunculuk Kongresi, 12-13 February, Izmir - Turkey, 55-62.

Kiraz, S., Akay, N., Vural, M. E., Karataş, A. \& Koncagül, S. (2014). Phylogenetic relationships based on mitochondrial DNA haplogroups between Güney Karaman and some local sheep breeds. International Participated Small Ruminant Congress: 372 . Konya.

Kırıkçı, K., Çam, M. A. \& Mercan, L., (2018). Genetic Diversity of the Karayaka Sheep Breed in Samsun. Turkey Scholars Bulletin (Veterinary Science), 680-684.

Koban, E. (2004). Genetic diversity of native and crossbreed sheep breeds in Anatolia (PhD thesis, Dept. of biology). Çankaya Ankara: School of natural and applied sciences of Middle East Technical University.

Kopelman, N. M., Mayzel, J., Jakobsson, M., Rosenberg, N. A., \& Mayrose, I. (2015). Clumpak: a program for identifying clustering modes and packaging population structure inferences across K. Mol. Ecol. Resour., 15(5), 1179-1191. https://doi.org/10.1111/1755-0998.12387

Langella, O. (1999). Populations (Version 1.2.32) [Population genetic software]. Retrieved from http://bioinformatics. org/ tryphon/populations/

Loukovitis, D., Siasiou, A., Mitsopoulos, I., Lymberopoulos, A. G., Laga, V., \& Chatziplis, D. (2016). Genetic diversity of Greek sheep breeds and transhumant populations utilizing microsatellite markers. Small Ruminant Research, 136, 238242. https://doi.org/10.1016/j.smallrumres.2016.02.008

Marshall, T. C. (2006). Cervus. (Version 3.0) [Cervus is a computer program for the assignment of parents to their offspring using genetic markers. Cervus, a Windows package for parentage analysis using a likelihood approach]. Retrieved from http://www.fieldgenetics.com

Miller, S. A., Dykes, D. D. \& Polesky, H. F. (1988). A simple salting out procedure for extracting DNA from human nucleated cells. Nucleic Acids Res 16, 1215. https://doi.org/10.1093/nar/16.3.1215
Montgomery, G. W. \& Sise, J. A., (1990). Extraction of DNA from Sheep white blood-cells. New Zeal J Agr Res, 33, 437-441. https://doi.org/10.1080/00288233.1990.10428440

Moulla, F. \& El-Bouyahiaoui, R. (2015). Populations ovines locales algériennes de la kabylie : Ressources génétiques animales méconnues et en danger d'extinction, In Workshop National: Valorisation des races locales ovines et caprines à faibles effectifs "Un réservoir de diversité génétique pour le développement local», 02-03 March, INRAA, Alger.

Naqvi, A. N., Mahmood, S., Vahidi, S. M. F., Abbas, S. M., Utsunomiya, Y. T., Garcia, J. F., \& Periasamy, K. (2017). Assessment of genetic diversity and structure of major sheep breeds from Pakistan. Small Ruminant Research, 148, 72-79. https://doi.org/10.1016/j.smallrumres.2016.12.032

Nei, M., Tajima, F. \& Tateno, Y. (1983). Accuracy of Estimated Phylogenetic Trees from Molecular-Data. 2. Gene-Frequency Data. Journal of Molecular Evolution 19, 153-170. https://doi.org/10.1007/BF02300753

Öner, Y., Üstüner, H., Orman, A., Yılmaz, O., \& Yllmaz, A. (2014). Genetic diversity of Kivircık sheep breed reared in different regions and their relationship to other sheep breeds in Turkey. Italian Journal of Animal Science, 13, 588-593. https://doi.org/10.4081/ijas.2014.3382

Paetkau, D., \& Strobeck, C. (1995). The molecular basis and evolutionary history of a microsatellite null allele in bears. Molecular Ecology, 4(4), 519-520. https://doi.org/10.1111/ j.1365-294X.1995.tb00248.x

Peakall, R., \& Smouse P. E. (2012). GenAlEx 6.5: genetic analysis in Excel. Population genetic software for teaching and research - an update. Bioinformatics, 28(19), 2537-2539. https://doi.org/10.1093/bioinformatics/bts460

Pritchard, J. K., Stephens, M., \& Donnelly, P. (2000). Inference of population structure using multilocus genotype data. Genetics, 155, 945-959.

Rambout, A., (2006). FigTree (Version 1.4.2.) [Computer software]. Retrieved from http://tree.bio.ed.ac.uk/

Ryder, M. L., (1983). Sheep and man. London: Duckworth.

Sassi-Zaidy, Y. B., Maretto, F., Charfi-Cheikhrouha, F., Mohamed-Brahmi, A., \& Cassandro, M. (2016). Contribution of microsatellites markers in the clarification of the origin, genetic risk factors, and implications for conservation of Tunisian native sheep breeds. Genetics and Molecular Research, 15(1). https://doi.org/10.4238/gmr.15017059

Sezenler, T., \& Özder, M. (2009). Türkiye'de merinoslaştırma çalışmaları. Hasad Hayvancılık Dergisi, 25, 34-41 (in Turkish).

TUIK. (2018). Türkiye İstatistik Kurumu Hayvancıllk istatistikleri. Retrieved from http://tuikapp.tuik.gov.tr

Yalcın, B. C. (1986). Sheep and goats in Turkey. (FAO Animal Production and Health Paper No. 60). Retrieved from http://www.fao.org/3/ah224e/AH224E00.htm

Yilmaz, M., Altin, T., Karaca, O., Cemal, I., Bardakcioglu, H. E., Yilmaz, O., \& Taskin, T. (2011). Effect of body condition score at mating on the reproductive performance of Kivircik sheep under an extensive production system. Trop Anim Health Prod., 43, 1555-1560. https://doi.org/10.1007/ s11250-011-9841-1 
Yilmaz, O., Cemal, I., \& Karaca O. (2014). Genetic diversity in nine native Turkish sheep breeds based on microsatellite analysis. Anim Genet, 45, 604-608. https://doi.org/10.1111/ age. 12173

Yilmaz, O., Cemal, I., Karaca, O., Ata, N., Sevim, S., \& Ozturk, M. (2013). Genetic diversity of Karya and Çine Çapari sheep. Scientific Papers Series D Animal Science, 56: 31-35.

Yllmaz, O., \& Karaca, O. (2012). Paternity analysis with micro- satellite markers in Karya sheep. Kafas Univ Vet Fak Derg, 18, 807-813 (in Turkish with abstract in English).

Yılmaz, O., Sezenler, T., Sevim, S., Cemal, İ., Karaca, O., Yaman, Y., \& Karadağ, O. (2015). Genetic relationships among four Turkish sheep breeds using microsatellites. Turkish Journal of Veterinary and Animal Sciences, 1411(46), 576-582. https://doi.org/10.3906/vet-1411-46 